\title{
3. KOMMENTAAR: OP LOOP GEJAAGDE OBJEKTIWITEIT
}

\section{J.J. SNYMAN}

Departement Wysbegeerte, RAU

Professor Wissing wil as "gelowige wetenskaplike" iets soos Satanisme in die massakultuur navors, aan die kaak stel en bestry met ' $n$ vertroue in die moontlikhede van moderne tegnologiese apparatuur. Ek wil nie ontken dat moderne klankapparaat onontbeerlik is vir die naspeur van moontlik versteekte boodskappe in populère musiek nie, maar om te reken dat die resultate van spektogramme uitsluitsel oor hierdie omstrede kwessie kan gee, wys in die rigting van in arm wetenskapsopvatting en in verengde wetenskapsmetodologie. Verantwoording oor belangrike veronderstellings en aannames kom nie op die tafel nie.

'n Baie belangrike aanname in die debat rondom backward masking is die vraag of daar ' $n$ houdbare analogie of gelykskakeling is tussen wat psigologies bekend is oor subliminale beïnvloeding deur visuele stimuli en wat vermoed word oor subliminale beïnvloeding deur oudiële stimuli. Die bekende voorbeeld is dié van die koeldrank-advertensie wat vir 'n breukdeel van 'n sekonde op die TV-skerm flits, en so - sonder dat ' $n$ mens as't ware die beeld bewus kon fikseer en agterna kan benoem - 'n onverklaarbare dors na daardie koeldrank by die kyker kan laat posvat. Die neuronale uitwerking van klankpatrone op die mens is ook bekend. Maar of daar 'n verband tussen hierdie twee stelle sintuiglike gewaarwordings getrek kan word, en of gesè kan word dat semanties fikseerbare stimuli via klankpatrone een of ander invloed op gedrag het, is twyfelagtig. Te veel gegewens moet nog hier ingevul word. Ek verwys na een so $n$ kwessie. Ons weet vandag dat mense se waardestelsel gemanipuleer kan word deur ingrepe op die elektro-chemiese prosesse van die brein. Indien popmusiek mense op 'n subliminale wyse tot (sè maar) bestialiteit beinvloed, moet nog verklaar word hoe musiek spesifiek popmusiek - die elektro-chemiese prosesse van die brein beinvloed. Hoekom popmusiek dit regkry, en nie byvoorbeeld Ravel se Bolero of Berlioz se Symphonie Fantastique nie (ook al by geleentheid die "simfonie van 'n cpiumroker" genoem, met sy heksesabbat en al), moet ook verklaar word. Die punt is dit: 'n hermeneutiek van suspisie lewer nie resultate op wat in 
terme van tegniese kontroleerbare en intersubjektief verifieerbare standaarde - waarop daar implisiet aanspraak gemak word - vertrou kan word nie. Daar bestaan byvoorbeeld lang tradisies oor teksgeheimenisse. Ek dink byvoorbeeld aan die Kaballah-tradisie. Dit is eerder die geloof aan die geheime en gekodeerde boodskappe in die teks as daardie geheime boodskappe self wat mense se gedrag beinvloed het.

'n Kwessie wat ook nog bewys moet word, is of en hoe mense wel back masking hoor. Dit is op hierdie punt dat die vermoede van 'n analogie tussen visuele subliminale persepsie en oudiële versteekte kodering nog nie bevestig is nie. Gestel daar kom in 'n liedjie die woorde maand ry èrens voor (om 'n voorbeeld uit die lys van professor Wissing se artikel te neem), en indien dit van agter teruggespeel sou word, of spektografies van agter af ontleed word, moet blyk dat Heer se naam die betekenis moet wees - wie hoor die so? Word hier nie te veel aan die onderbewuste vermoëns van die mens toegeskryf nie? Word hier nie te gou, onder die dekmantel van wetenskaplike objektiwiteit en tegnologiese sofistikasie, spoke opgejaag nie? As so iets wel gebeur omdat die tegniek nou eenmal bekend is, en daar is ook in repertorium van spektogramme in $n$ taal bekend, verander dit nog niks aan die vraag nie. Die feit is dat die versteekte semantiese eienskappe van die gebruikte taal (die back masking) nie in die aanbod hoorbaar is soos wat dit oënskynlik bedoel word nie, en eers deur in tegniese ingreep en spektografiese ontleding waarneembaar word.

Maar tog bly mense geheime magte - ook in tekste - vrees. Waarom, en juis vandag ook? In die beantwoording van hierdie vraag kom verdere, tegnies onkontroleerbare aannames in die kwessie van die bestryding van Satanisme na vore.

'n Eerste aanname is die van 'n verborge komplot. Die vermoede van Satanisme kom gewoonlik saam met sienings voor oor sameswerings van allerlei aard in die sosiale, ekonomiese en politieke sfeer. Oor die juistheid hiervan al dan nie, wil ek nie in besonderhede ingaan nie.

Wat wel belangrik is, is dat die problematiek waarvoor die individu voel dat hy te staan kom, hierdeur in 'n dimensie van 'n oorweldigende orde, en spesifiek op 'n verwyderde vlak - buite die bereik van sy vermoëns geprojekteer word. Dit sê iets van homself, eerder as van die (vermeende) 
kwaad wat hy identifiseer. Komplotteorieë en die vrees vir Satanisme is soos die heksejagte van vroeër, eerder simptome van 'n kultuur en samelewing waarin mense hulle magteloos voel, en vir hierdie gebrek aan sekuriteit wil vergoed word deur 'n stryd wat 'n metafisiese - bo-aardse - waardigheid verkry om sodoende $\sin$ aan hulle bestaan te verleen. ' $n$ Mens kry die indruk dat kruisvaarders teen Satanisme se geloof in Satan miskien selfs sterker is as hulle geloof in Christus. Die oorheersende indruk wat hier van die wèreld en van die hedendaagse kultuur gewek word, is dié van 'n listige en oppermagtige bedreiging. Ek wonder baie keer wat is die sosiale funksie van hierdie bedreigingsindroom? Is dit nie 'n uitdrukking van die onvermoë, onmag én onwilligheid van 'n bepaalde tipe individu om die werklike probleme van sy tyd en omgewing die hoof te bied nie?

'n Tweede aanname word uit hierdie diepliggende gevoel van onmag gebore. $\checkmark$ reemd soos dit mag klink, het hierdie tweede aanname te make met 'n magsmotief. In die hedendaagse massakultuur beleef baie mense hulleself as kulturele, sosiale, ekonomiese en politieke voyeurs. Hulle staan as't ware deur 'n sleutelgat en loer na ' $n$ wèreld wat 'n invloed op hulle het, maar wat hulle nooit volledig in die prentjie kry en daarom nooit volledig verstaan nie. Kom iemand met die aanspraak dat hy/sy die verborgene vir Jan Publiek kan ontsluit, en word hierdie aanspraak met tegniese apparaat (rekenaars, meetinstrumente, waarneembare demonstrasies) gerugsteun, is die gesaghebbendheid bykans volkome. Die onsigbare word sigbaar vasgepen. Dit is dan baie moeilik om die eertydse voyeur te oortuig dat hy eintlik nog nie alles in die greep het nie, dat lets hom steeds bly ontgaan, naamlik sy betower wees deur wat hy warneem. Die punt is: die afruk van die sluier is nie die kuur nie, mar die emansipering van die voyeur-individu.

Ek dit bring my by die derde aanname, en eintlik die een waarmee ek begin het: tegnies-kontroleerbare feite in verband met werklike en vermeende subversiewe boodskappe in produkte van die massakultuur hou mense onmondig in die massakultuur, en gee aan sekere tipes kultuurleiers 'n mag oor mense wat gevaarlik is. Mense word deur vrees tot kulturele vroomheid geïntimideer, en daardeur kultureel onmondig gehou. Ek wil dit nog skerper en aanvallender sè: 'n vlak, literalistiese Skrifhermeneutiek word deur 'n beroep op 'n scientisties verskraalde kultuurhermeneutiek gerugsteun om deur vrees kerklike invloed te probeer behou op 'n terrein war die problematiek van menswees, samelewing en oorlewing in skrikwekkende dieptes afgetas is. 
Die vraag is of die hermeneutiek van die Skrif by baie gelowiges só diepgaande is dat dit in staat is om die probleme van die hedendaagse kultuur te kan uitlè. Verstaan mense die funksies en taal van die hedendaagse massakultuur ten einde krities daarmee te kan omgaan? Sè die dialektiek van die Verligting iets? Hiersonder is die kanse goed dat daar geen grens is tussen Satansvrees en Satansgeloof nie, ook by diegene wat onder die vromes getel wil wees. 